\title{
Neoteric Performance Challenges for Islamic Banks: An Elucidation
}

\author{
Areeba Khan, Junaina Muhammad \\ University Putra Malaysia, Selangor, Malaysia
}

\begin{abstract}
This paper aims to examine the challenges posed to the global banking environment with the advent of phenomenal growth in Islamic banking and the changing macroeconomic environment. The paper reviews different approaches to analyze the banking sector performance and the success or failure thereof. The paper also identifies the main factors affecting banking sector performance and their relative impact on the overall stability and resilience of banks. The approach of this paper is more judiciously diagnostic and synthesizing in nature. The paper covers significant studies undertaken in banking sector and synthesizes the nature of elements used to predict the predilection status of Islamic and conventional commercial banks. The findings suggest that return on equity (ROE) and weighted capital adequacy ratio (WCAR) are the most important bank-specific factors that may be used to analyze bank's performance. The findings also suggest that not only bank-specific but macroeconomic factors also play an important role in determining a bank's performance in an economy, though the effect is usually widespread. Amongst macroeconomic factors, GDP growth rate, inflation, and real interest rate are most common factors affecting bank performance. This research is different from other researches as it takes into consideration the methodological, aeon and acclimatization perspective. Most researches do not see Islamic banking as a challenge to conventional commercial banking and the banking sector in general. The paper not only reviews Islamic banking as a major element of change in the overall banking environment but also as a potential intimidator to the conventional banking stream.
\end{abstract}

Keywords: bank performance, Islamic banking, comparison, resilience, Z-score, macroeconomic factors

\section{Introduction}

Wilson (1997) stated:

Islamic banking is no more viewed as a business element endeavouring just to satisfy the religious commitments of the Muslim group, yet all the more essentially, as a business that is ineluctably in requirement for winning over clients in the meantime as holding the old ones. (Wilson, 1995; Dusuki \& Abdullah, 2007)

The phenomenal growth in Islamic banking industry is based on a few factors, namely, the need for Shariah compliant products, strengthening of Islamic regulatory framework and diversification of capacity and scope to innovate new products (Hasan \& Dridi, 2010). Much of the growth of Islamic banking is concentrated in regions of Middle East and South Asia. In the aftermath of September 11, 2001, considerable amount of savings of Arab World transferred back from West to the Gulf Cooperation Council (GCC) region, which was an influx that gave a boost to Islamic banking in that region. 


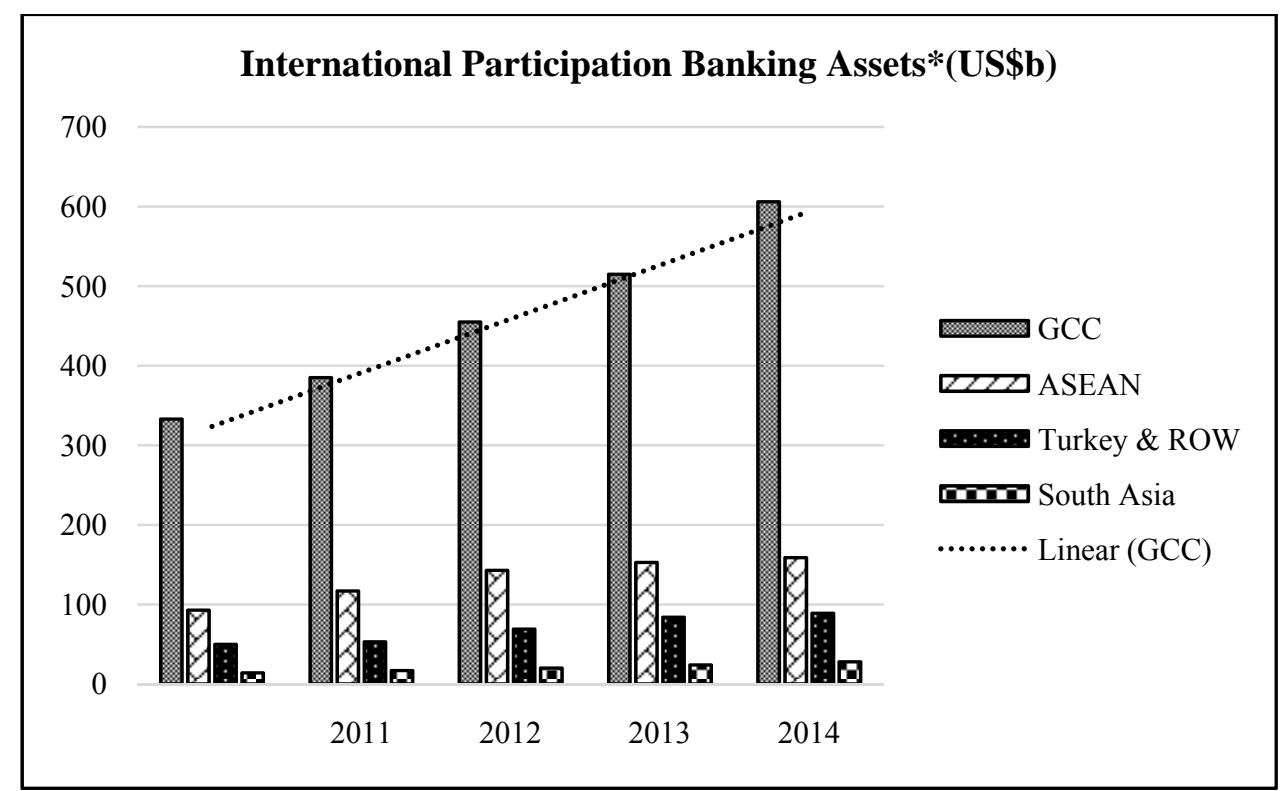

Figure 1. Growth in Islamic banking assets (Earnest \& Young, 2014).

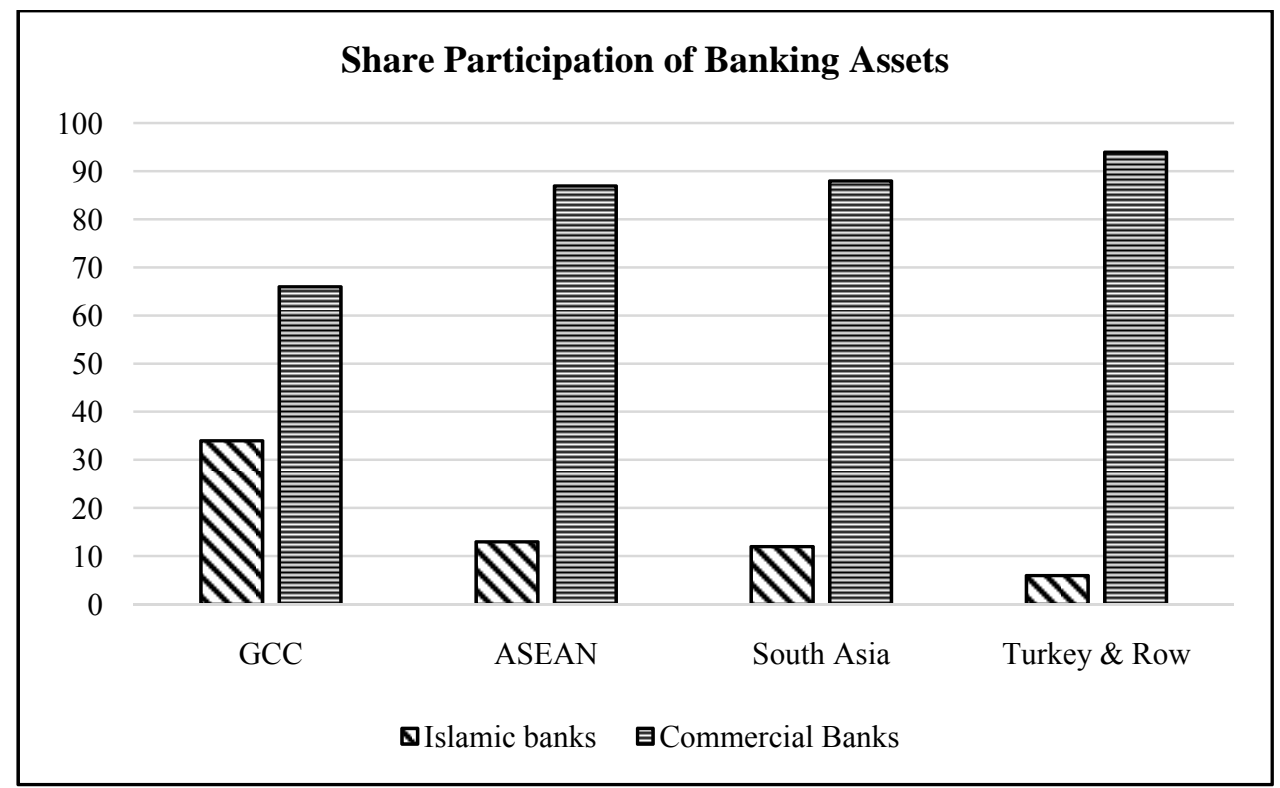

Figure 2. Market share of Islamic and commercial banks in participation banking assets (Earnest \& Young, 2014).

Figures 1 and 2 exhibit the growth of Islamic banking assets in prominent regional clusters, as well as against their conventional counterparts. The growth rate in Islamic banking assets hovers around an average of $16 \%$ throughout 2010-2014, with the largest part of the market concentrated in the GCC region roughly about $\$ 606$ billion, followed closely by the ASEAN region at $\$ 159$ billion. The great pace of growth in assets would have generally meant higher profit margins as compared to contemporaries, but looking at return on investments (ROI) of Islamic banks (IBs), it is a totally different story. The industry's average ROI is $12 \%$ as compared to $15 \%$ of commercial banks (CBs) in the year 2011. 
The total number of registered IBs as of June 2014 is 157 , with the majority registered in Middle East, Far East, and Africa (see Figure 3).

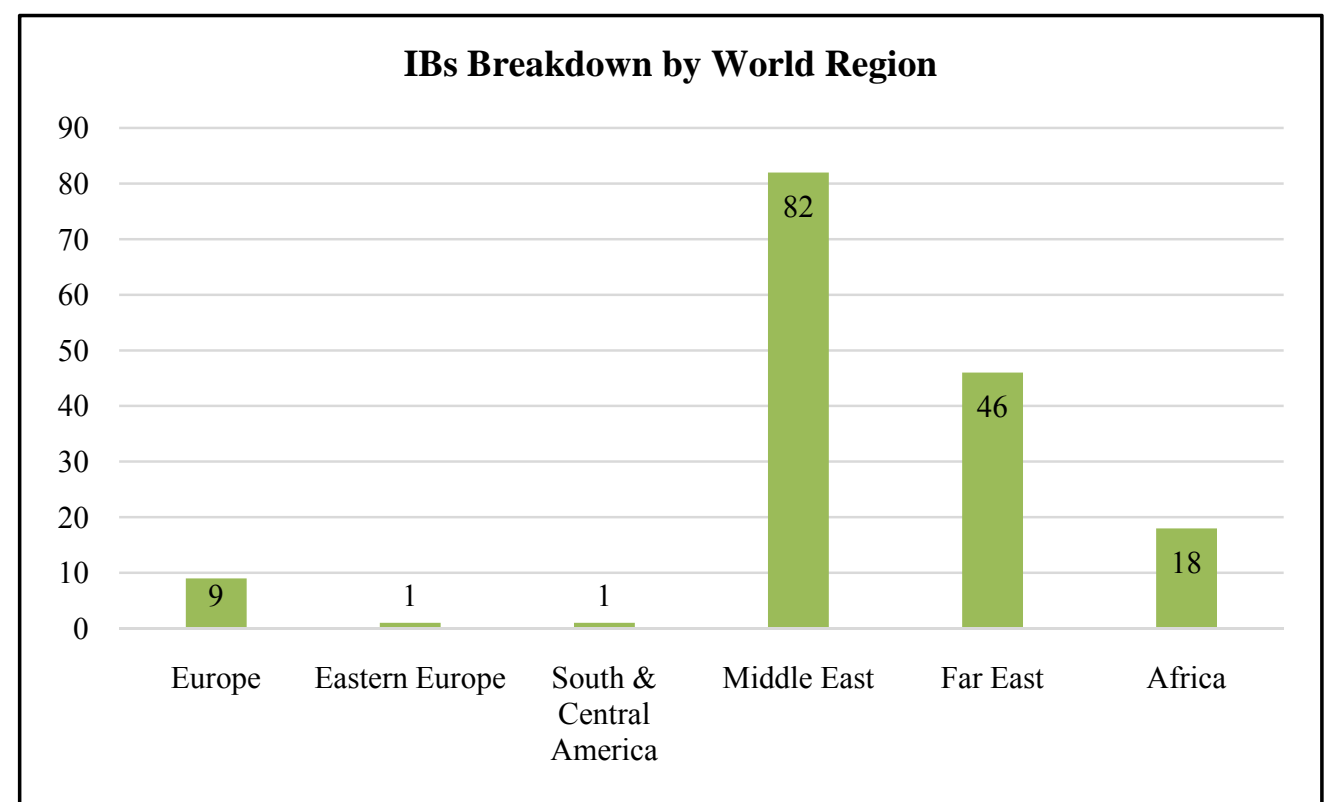

Figure 3. Islamic banking breakdown by world region. Source: Author calculation from BANKSCOPE.

IBs and CBs play more or less the same role for the economy by effectively mediating the savings and bringing mediating and transaction costs to a lower level. However, conducting same level of business, IBs are exposed to different kinds and magnitude of risk as compared to conventional CBs, owing to usage of Shariah compliant modes of finance by IBs. They have to face multiple challenges regarding sub-scale operations, asset quality, negative operating income from core activities, and weak risk management culture. Where CBs are largely debt-based and allowed for risk transfer, IBs are asset-based and focus on risk sharing.

IBs operate on principles of Islamic Shariah which are significantly different than those practised by CBs. Islamic paradigm of finance encourages risk sharing through equity investments and prohibits the use of interest (Riba), as it is believed that interest-based financial systems lead to unequal distribution of wealth (Olson \& Zoubi, 2008). In contrast, the commercial bank financing and investment is primarily based on interest, guided by principle of profit maximization.

\section{Issues and Challenges of the Banking Sector}

Regulation has emerged as a great concern for the banking sector after the crisis of 2009. It was unveiled that the then existing regulatory structure was not prudent enough to help avoid practices which may increase default risk of banks. Concerns about imprudent and reckless banking practices led to BASEL II and BASEL III, as it was found that in pursuit of profitability and efficiency, the resilience aspect was being ignored by banks. BASEL II \& III introduced new ratios like liquidity coverage ratio (LCR) and net stable funding ratio (NSFR) to ensure banks built cushions for liquidity and stable financing and maintain the quality of assets.

The second most pertinent regulatory question is whether IBs require the same intensity and kind of prudential oversight as conventional institutions? In economies where IBs and CBs co-exist, there is usually the same prudential regulation structure that covers both the paradigms. 
In economies where both IBs and CBs exist is parallel banking system, it is likely that the statutes of regulations do not include all the shariah rules that ought to represent Islamic finance. Nonetheless, DeLorenzo (2007) called attention to, in most of the regimes, the legal framework is commonly sufficiently adaptable to permit the drawings of contracts in whatever way the parties may deem suitable. As is brought to attention by Errico and Farrahbaksh (1998), El-Hawary, Grais, and Iqbal (2004), Solé (2007), and Čihák and Hesse (2008) among others, there are sure elements of IBs that warrant more prudential regulation than traditional banks. These contemplations incorporate moral hazard, investor protection and preservation of depositor's interests, as well as systemic contemplations. Notwithstanding administrative issues, resilience and stability concerns also dominate the present scenario.

A few researchers, including Beck, Demirgüç-Kunt, and Merrouche (2013), have contended that the risks postured to the monetary framework by IBs vary significantly from those postured by CBs. Risks pertinent to IBs might emerge straightforwardly from the particular components of Islamic contracts, and additionally by implication from the general statutory, administrative and liquidity management framework adopted by institutions of Islamic finance. For instance, PLS financing disseminates the immediate credit risk from banks to their term depositors. However, it amplifies the level of risk on the asset side of banks' balance sheet, since it makes IBs susceptible against dangers ordinarily borne by equity investors instead of debtors.

This may however be contradicted by real life practices of IBs. In practice, there is more convergence in banking practices of IBs and CBs, owing to the fact that most Islamic banking contracts are mark-up based contracts. PLS-based contracts like Mudarabah and Musharakah are rarely executed and do not hold preponderance. Therefore, IBs and CBs are exposed to almost same magnitude of risk in this regard.

The absence of viable Islamic money markets may however result in higher liquidity risks for IBs. While Sukuk are organized similar to regular asset-based securities (ABS) or secured bonds, they can have essentially distinctive contractual obligations and procurements. Sukuk are commensurate to Islamic securitization, which, through a shariah-consistent credit transaction or some trust-based instrument, alters reciprocal risk sharing amongst borrowers and banks into the market administered refinancing agreement. However, it is difficult to regulate their structure through the same regulation, thereby calling for market mechanisms to come into play.

Corporate governance concerns also constitute a major issue faced by the banking sector. The code of corporate governance introduced in various countries covers all sectors of the economy regardless of their nature. However, banking sector is different from other corporate sectors of economy owing to its service-based nature of operations and intermediation role that connects different sectors of economy as well as individuals and monetary regulation authorities. So far, no separate corporate governance rules and regulations have been developed for the banking sector. Therefore, the present corporate governance regulations are just about superficial compliance rather than addressing the real issues faced by the sector.

For IBs, the situation is even more gruesome as they have a Shariah board in addition to the code of corporate governance, decreeing their governance structure. Van Greuning and Iqbal (2008) highlighted five issues identifying with Shariah board. The primary issue he talks about is its freedom from administrative control. He contended that the services of members of Shariah board are utilized by bank and they are compensated and endorsed by board of directors. This can result in a double-layered agency problem and can give rise to irreconcilable circumstance. This can also prompt loss of investor confidence and increase liquidity and other risks. 
Khan (2010) likewise accentuated on independence of Shariah board and contended that these concerns can be alleviated by having a free Shariah board. Errico and Farahbaksh (1998) examined internal control mechanism of IBs and examined in detail the effect of Shariah advisory board's control over structure of instruments.

Product diversification and hedging is also a concern for the banking sector, as the fast pace of innovation of instruments and vehicles of finance is making the vigilance more difficult and the operational environment more complicate. Multiple layers of securitization on one hand hedge for the risk and on the other hand increase the stakes for the investors. Banks are increasingly being involved in horizontal diversification also by entering into businesses such as leasing and insurance company under the same corporate umbrella.

Rapid pace of development in hedging instruments has also made it easier for banks to mitigate risk. This is however not a very plausible option for IBs as in many countries they are not allowed to hedge risk by using hedging instruments like derivatives. Also, most of the IBs do not have a variety of Shariah complaint products to offer. Till date, there are 12 modes of Islamic finance permissible under Shariah and all products developed have to correspond to these 12 modes of finance.

Owing to the lack of professional expertise in the area, many banks in different countries stick to generic products like Mudarabah and Musharakah without taking into consideration customer preferences and market needs. Though hedging instruments are not been used extensively by IBs, Smolarski, Schapek, and Tahir (2006) studied alternatives from Islamic perspective and concluded that derivative choices might be allowed for supporting purposes in Islamic finance. They contended that if the basic financial service is itself admissible from Islamic perspective then there should be no problem in usage of derivative securities based on that financial service.

Contagion effect of the financial crisis is another important area of concern for the banks as most of the banks are involved in interrelated transactions and operate in confederacy, the relative impact of crisis is easily transferrable in case of shock waves throughout the region. IBs had managed to avoid the contagion effect from global financial crisis, but experienced the shockwaves through the second cycle of contagion more profusely. Therefore, the financial resilience of banks is important not only for their own stability but also for stability of economy and other banks that may be subject to shockwaves generated by debacle of few.

The lack of direction on shari'ah consistent securitization structure influences the legitimate enthusiasm of the Sukuk investors. Investors of Islamic finance are not just worried about the consistence of both securitized resources and the exchange structure with the shari'ah additionally with lawful enforceability of cases regarding asset claims under contract law. So from a financial specialist's point of view, both the asset-based contract and nature of transaction must satisfy the requirements of not only Islamic Shariah but also the prevalent commercial system. Therefore, up gradation of the legal environment is also an imperative for the banking sector.

\section{Determinants of Bank Performance}

Extensive research has been carried out in identification of factors that may affect bank performance and their relative impact. There are two distinct types of bank performance determinants: macroeconomic developments (systematic risk) and firm-specific factors (idiosyncratic factors). There is exhaustive literature present that tries to distinguish which bank specific factors are the best indicators of bank performance. Subsequent to the greater part of this exploration has been completed in the US (with its vast populace of banks and long history of bank liquidations), the work for the most part spotlights on demonstrating the probability of bank failure. 
The majority of the studies conclude upon capital adequacy and earnings as most helpful predictors of the likelihood of distress and bankruptcy (Demirguc-Kunt \& Detragiache, 1998). Furthermore, fast development of lending mechanisms tends to build more risk into the system (Keeton, 1999). Mathematical models elaborating upon the probability of bankruptcy and time to failure, find that fundamental markers of a bank's condition, for example, capital, net income and non-performing loans are additionally vital determinants of the timing of bank disappointment (Cole \& Gunther, 1998).

However, the focus has been generally misplaced. Capital adequacy ratio is more of a conformance issue. Banks have to comply with the prudential regulations and maintain a limit of capital adequacy ratio. Similar goes for profitability. Banks pursue all avenues where they can achieve maximum profit efficiencies. The pertaining question here is: "Can a bank that maintains a good capital adequacy ratio and good profitability level file for default?". The answer is yes. Global financial crisis of 2009 saw the debacle of banks which had maintained capital adequacy ratio and profit levels yet filed for bankruptcy. In such a scenario, what is the predictive capacity of capital adequacy ratio and profitability as standalone contributors to performance evaluation? There must be something missing. The answer is asset quality, leverage and liquidity. These are the aspects grossly ignored by many of the efficiency and profitability researchers.

Another rather interesting issue is whether non-financial indicators like proprietorship status of a bank have the capacity to anticipate its flexibility and efficiency? Little confirmation is found to bolster the hypothesis that private institutions will return generally higher economic benefits. Short (1979) is one of only a handful few studies offering cross-country proof of a compulsive negative relationship between public ownership and bank benefit. In their late work, Barth, Caprio, and Levine (2001) claimed that public ownership is in fact adversely related with bank efficiency. Interestingly, Bourke (1989; as cited in Bokpin, 2013) and Molyneux and Thornton (1992) reported that ownership status does not have a conclusive impact on efficiency. However, this area needs more exploration and constitutes an interesting aspect of study that may not only give an insight on the corporate governance structure of bank but also decision-making mechanisms.

The macroeconomic variables normally used to determine impact on bank performance are the inflation rate, the long-term interest rate, and/or the growth rate of money supply. Revell (1979) presented the issue of the relationship between bank efficiency and inflation. He noticed that the impact of inflation on bank efficiency relies upon whether banks' wages and other administrative costs increment at a higher rate than inflation. In this regard, Perry (1992) stated that the degree to which inflation influences bank efficiency relies on upon whether expectation of inflation is completely realized.

An inflation rate completely expected by the bank's administration infers that banks can fittingly alter interest rate keeping in mind the end goal to build their incomes faster than their expenses and subsequently procure higher monetary benefits. Most studies (counting those by Molyneux \& Thornton, 1992; Bourkhis \& Nabi, 2013) have demonstrated a positive relationship between either inflation or interest rate and efficiency.

The question remains however, in presence of endogeniety and extensive correlations between inflation, interest rate, exchange rate and GDP growth rate, how can the magnitude of impact of growth and stability of financial sector on growth of economy be isolated?

As per Swamy (2013), it is necessary to control for the macroeconomic variables to observe their impact on bank resilience separate from bank-specific factors. Therefore, a vector of GDP growth rate, inflation rate, real interest rate, and exchange rate depreciation is taken to represent the major macroeconomic variables. The GDP growth rate is supposed to affect the bank resilience and stability in a positive manner by contributing towards growth of the financial sector as a whole. 
The pattern of GDP influences the interest for banks resource. Amid the declining GDP development the interest for credit falls, thus adversely influencing the profitability of banks. Despite what might be expected, in a developing economy as communicated by positive GDP development, the interest on credit is high because of the business cycle. Amid boom the demand for credit is high contrasted with the time of distress (Athanasoglou, Brissimis, \& Delis, 2005).

Inflation rate is supposed to exert a negative influence on bank performance as real rate of return would decrease. However, relationship between inflation level and banks profitability remains debatable as the direction of the relationship is not clear (Vong \& Chan, 2009).

Similarly, exchange rate depreciation is supposed to have a positive impact on bank resilience and stability. All else equal, growth in aggregate output and income will strengthen firms' and households' ability to service their debt, meet their obligations and in turn, improve bank stability (Kaufmann, 1998). Over longer horizons however, these relationships may be less clear or even work in the opposite direction. An acceleration in output growth may lead to excessive lending and generate risk of bank fragility.

The array of time-variant bank characteristics that might confound the relationship between bank types are being controlled for, from one viewpoint, and business introduction, resource quality, effectiveness, and security, then again. In particular, this study controls for bank size, utilizing the log of aggregate resources. Bigger banks may be more productive because of scale economies, while the hypothetical and exact writing on the relationship in the middle of size and strength is questionable (Beck et al., 2013).

The proportion of altered resources for aggregate resources is controlled for the open door costs that emerge from having non-gaining resources on the monetary record, and additionally the offer of non-enthusiasm acquiring advantages for control for non-loaning business of banks, which past examination has appeared to influence both proficiency and steadiness of banks (Demirgüç-Kunt \& Detragiache, 1998). Concerning the bank particular variables, the net credits to aggregate resources proportion is observed to be negative and measurably noteworthy at 5\% level of danger for the little banks (Bourkhis \& Nabi, 2013).

At that point, banks with limited profitability and higher advances are considered less stable. The coefficient of the expense to wage proportion is likewise anticipated that would be negative. The more proficient banks are the more stable ones. The wage assorted qualities does not seem huge in every one of the relapses completed in past studies. With respect to administration, there is some proof that it negatively affects the banks' soundness (Hasan \& Dridi, 2010). Conversion scale deterioration and genuine GDP development have no unmistakable straight reliance with the $Z$-score as hypothesized in studies by Bourkhis and Nabi (2013) and Beck et al. (2013), however as per economic theory they are expected to have a some positive impact on banking performance, even if not too profound.

\section{Conclusion}

The study aims at providing the researchers and practitioners with a better understanding of the banking sector, and the level of divergence that IBs experience from conventional banking practices. The study has also highlighted factors that affect both banking regimes, e.g., return on assets (ROA), return on equity (ROE) and weighted capital adequacy ratio (CARWTD) and must be administered and regulated to maintain and improve health of financial firms. 
A higher capital adequacy ratio may support the stakeholders of the bank, but it eventually results in a decrement in performance of the bank, as the bank has to choose between raising capital or lowering down its lending activities, which are both difficult decisions to carry out, owing to their cost and execution. This may control the risk appetite of banks but decrease the bank's profitability. Therefore, minimum capital adequacy ratio should be set for the banks to comply with, in order to provide a better footing to the bank in the long term.

The link between liquidity and risk tolerance can strengthen the applicability of an effective monetary policy. Therefore, while devising the monetary policy, the governments should take into consideration the liquidity component of market, liquidity management and hoarding behaviour of banks and how a liquidity multiplier can effectively control these two to attain a perfect balance.

Compliance and regulation must be made more transparent to focus on factors that may affect firm's health. The focus of the new measures may not be on efficiency but financial resilience of the firm. Most of the economies are considering BASEL III as a magic wand, application of which would increase the resilience of the financial system and deliver better results for the economy.

\section{References}

Athanasoglou, P. P., Brissimis, S. N., \& Delis, M. D. (2005). Bank-specific, industry-specific and macroeconomic determinants of bank profitability. Bank of Greece.

Barth, J. R., Caprio, G., \& Levine, R. (2001). Banking systems around the globe: Do regulation and ownership affect performance and stability? In F. S. Mishkin (Ed.), Prudential supervision: What works and what doesn't. National Bureau of Economic Research.

Beck, T., Demirgüç-Kunt, A., \& Merrouche, O. (2013). Islamic vs. conventional banking: Business model, efficiency and stability. Journal of Banking \& Finance, 37(2), 433-447.

Bokpin, G. A. (2013). Ownership structure, corporate governance and bank efficiency: An empirical analysis of panel data from the banking industry in Ghana. Corporate Governance: The International Journal of Business in Society, 13(3), $274-287$.

Bourkhis, K., \& Nabi, M. S. (2013). Islamic and conventional banks' soundness during the 2007-2008 financial crisis. Review of Financial Economics, 22(2), 68-77.

Čihák, M., \& Hesse, H. (2008). Islamic banks and financial stability: An empirical analysis. IMF Working Paper Series.

Cole, R. A., \& Gunther, J. W. (1998). Predicting bank failures: A comparison of on- and off-site monitoring systems. Journal of Financial Services Research, 13(2), 103-117.

DeLorenzo, Y. T. (2007). Shari'ah compliance risk. Chicago Journal of International Law, 7(2), 397-408.

Demirguc-Kunt, A., \& Detragiache, E. (1998). The determinants of banking crises in developing and developed countries. IMF Staff Papers, 45(1), 81-109.

Dusuki, A. W., \& Abdullah, N. I. (2007). Maqasid al-Shari ah, Maslahah, and corporate social responsibility. The American Journal of Islamic Social Sciences, 24(1), 26-45.

Dusuki, A. W., \& Abdullah, N. I. (2007). Why do Malaysian customers patronize Islamic banks? International Journal of Bank Marketing, 25(3), 142-160.

Earnest \& Young. (2014). World Islamic Banking Competitiveness Report 2013-2014.

El-Hawary, D., Grais, W., \& Iqbal, Z. (2004). Regulating Islamic financial institutions: The nature of the regulated. World Bank Policy Research Working Paper 3227, March 2004.

Errico, L., \& Farahbaksh, M. (1998). Islamic banking: Issues in prudential regulations and supervision. IMF-Working Papers Series.

Hasan, M., \& Dridi, J. (2010). The effects of global crisis on Islamic and conventional banks: A comparative study. IMF Working Paper Series.

Kaufmann, D. (1998). Myths and realities of governance and corruption. World Bank.

Keeton, W. R. (1999). Does faster loan growth lead to higher loan losses? Economic Review, 84(2), 57-75.

Khan, F. (2010). How 'Islamic' is Islamic banking? Journal of Economic Behavior \& Organization, 76(3), 805-820. 
Molyneux, P., \& Thornton, J. (1992). Determinants of European bank profitability: A note. Journal of Banking \& Finance, 16(6), 1173-1178.

Olson, D., \& Zoubi, T. A. (2008). Using accounting ratios to distinguish between Islamic and conventional banks in the GCC region. The International Journal of Accounting, 43(1), 45-65.

Perry, P. (1992). Do banks gain or lose from inflation? Journal of Retail Banking, 14(2), 25-30.

Revell, J. (1979). Inflation and financial institutions. London, UK: Financial Times Ltd..

Short, B. K. (1979). The relation between comemrcial bank profit rates and banking concentration in Canada, Western Europe, and Japan. Journal of Banking \& Finance, 3(3), 209-219.

Smolarski, J., Schapek, M., \& Tahir, M. I. (2006). Permissibility and use of options for hedging purposes in Islamic finance. Thunderbird International Business Review, 48(3), 425-443.

Solé, J. (2007). Introducing Islamic banks into Commercial banking systems. IMF Working Paper Series.

Swamy, V. (2013). Eurozone debt crisis: Implications for the Indian banking sector. International Finance Review, 14, $341-362$.

Van Greuning, H., \& Iqbal, Z. (2008). Risk analysis of Islamic banks. Washington, USA: The International Bank for Restructuring and Development.

Vong, A. P. I., \& Chan, H. S. (2009). Determinants of bank profitability in Macao. Faculty of Business Administration, University of Macau.

Wilson, R. (1997). Economics, ethics and religion: The Jewish, Christian and Muslim economic thought. London: Macmillan. 